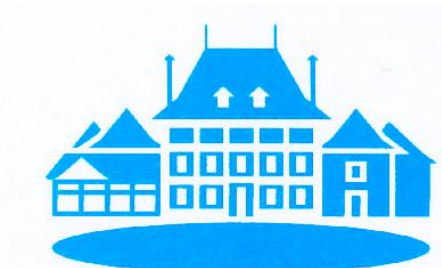

STUDY CENTER

GERZENSEE

\title{
CHF Strength and Swiss Export Performance - Evidence and Outlook From a Disaggregate Analysis
}

\author{
Raphael Auer and Philip Saure
}

Working Paper 11.03

This discussion paper series represents research work-in-progress and is distributed with the intention to foster discussion. The views herein solely represent those of the authors. No research paper in this series implies agreement by the Study Center Gerzensee and the Swiss National Bank, nor does it imply the policy views, nor potential policy of those institutions. 


\title{
CHF Strength and Swiss Export Performance - Evidence and Outlook From a Disaggregate Analysis ${ }^{1}$
}

\author{
Raphael Auer and Philip Saure \\ (Swiss National Bank) (Swiss National Bank)
}

Zurich, 29 March 2011

\begin{abstract}
:
Why has Swiss export performance been so strong during the past quarters despite the marked appreciation of the CHF? What is the outlook for Swiss exports given the still elevated CHF? In this paper, we shed light on these questions by analyzing a panel of Swiss exports disaggregated along both the regional and the industry dimension. To explain the export performance of the recent past, we estimate how the exchange rate and demand growth in each export market affect trade flows and also, how this varies across different industries. The appreciation of the CHF has considerably dampened Swiss export performance. As a counterfactual, we ask how Swiss exports would have developed had the CHF stayed flat against other currencies during the 5 years leading up to 0ctober 2010. Compared to this scenario, the Swiss export industry has already lost a cumulative of $\mathrm{CHF} 35$ billion in revenues due to the CHF appreciation. At the current juncture, monthly exports are reduced by CHF 2.7 billion (around 17\%).

We show that the key reason for the strong export performance despite the CHF strength was the rebound in global demand in the aftermath of the financial crisis. Moreover, we also document that the timing of global demand growth has completely masked the effect of the CHF strength: during the last quarters, periods of pronounced CHF appreciation always coincided with strong recovery of global demand. Failure to account for this coincidence could lead to the wrong assumption that the exchange rate matters very little for Swiss export performance.

Last, to gauge the likely evolution of Swiss exports and their regional composition in the years to come, we combine our estimation results with the regional GDP and exchange rate forecasts provided by the Swiss National Bank. Following this approach, we predict that over the next three years, Swiss exports will rise a combined $16 \%$, with little less than half of this increase going to Emerging Asia and 30\% to the euro zone. We also document the key industries that will drive Swiss export growth in the near future.
\end{abstract}

\footnotetext{
${ }^{1}$ Contact: Raphael.Auer@SNB.ch and Philip.Saure@SNB.ch. We thank Andreas Fischer, Andreas Kropf, and Caroline Schmidt for comments and Andreas Kropf for providing excellent research assistance.
} 


\section{Exchange Rates and Demand Growth as Drivers of Swiss Exports}

Figure 1 displays the evolution of Swiss imports and exports since January 2005 on the left axis and the evolution of the trade weighted $\mathrm{CHF}$ exchange rate on the right axis. The volume of Swiss exports rose steadily during the last months despite the substantial appreciation of the

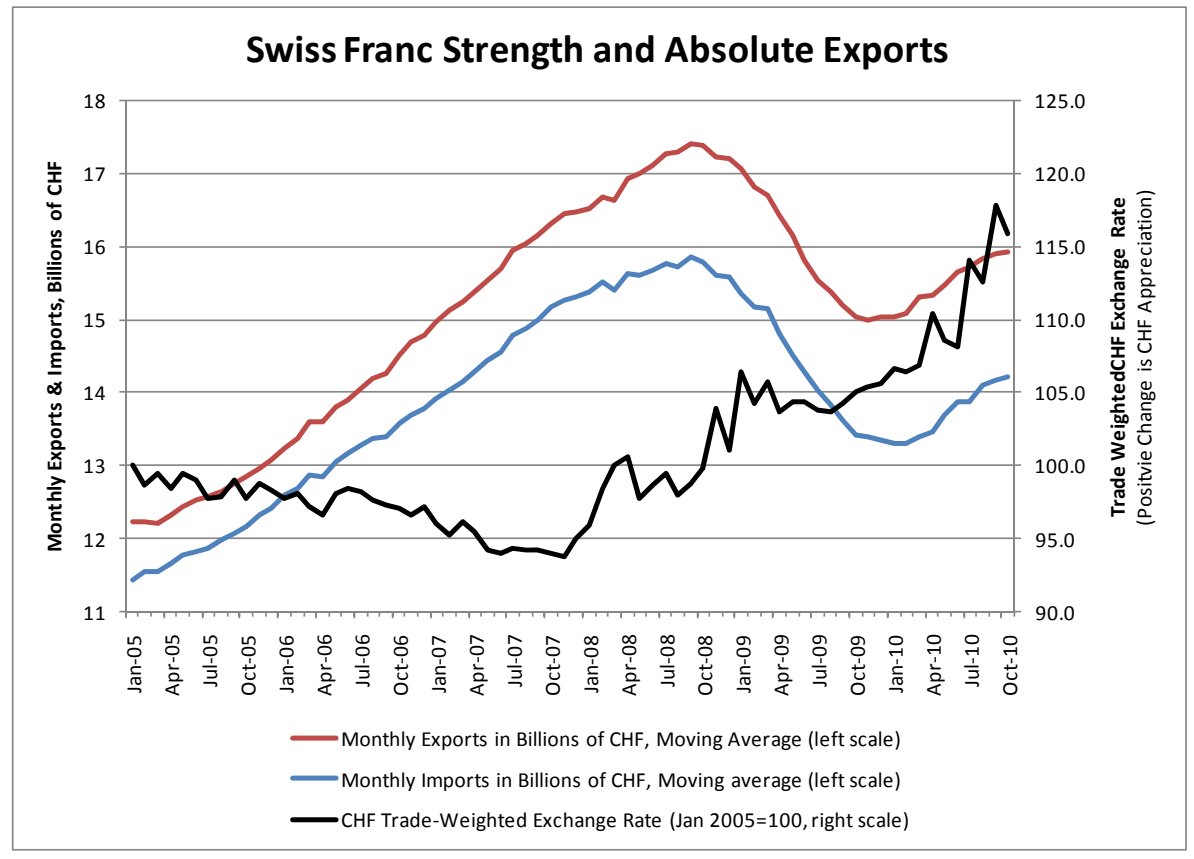

Figure 1

CHF.

How can this be explained? Demand for Swiss products is likely to grow whenever expenditure in its export markets rise. Conversely, demand for Swiss products falls when the CHF appreciates against the trade partner's currency. We next evaluate to what extent the recent Swiss export performance can be explained by these two broad patterns.

\subsection{The Geography of Recent Swiss Export Growth}

During the last quarters, Swiss exports recovered strongly as the effects of the financial crisis abated. We start by looking at the geographic dimension of this recovery. Figures 2 and 3 relate Swiss exports to bilateral exchange rates and foreign GDP, all in terms of changes.

Figure 2 displays the relation between the change in the bilateral exchange rate and bilateral Swiss export growth. Changes are measured from 2009:02 to 2010:02; the sample includes Switzerland's 40 most important trade partners. The growth of Swiss exports to the corresponding export market is displayed on the vertical axis. Exchange rate changes are on the horizontal axis. The bilateral exchange rate is measured as $\mathrm{CHF}$ over local currency so that a positive change reflects an appreciation of the CHF against the currency in question, making Swiss exports more expensive. 
As intuition suggests, those countries facing the largest depreciation against the $\mathrm{CHF}$ tended to demand the least Swiss goods. However, Figure 2 also suggests that the relation is not very pronounced: the displayed regression line implies that a $20 \%$ appreciation of the CHF is roughly associated with a $10 \%$ decrease of exports to the respective trading partner.

Figure $\mathbf{3}$ presents the corresponding relationship between GDP growth in the export market and growth of Swiss exports. Here, the horizontal axis represents GDP growth of the trade partner. There is a pronounced positive relation between trade partner GDP growth and

Swiss export growth. The

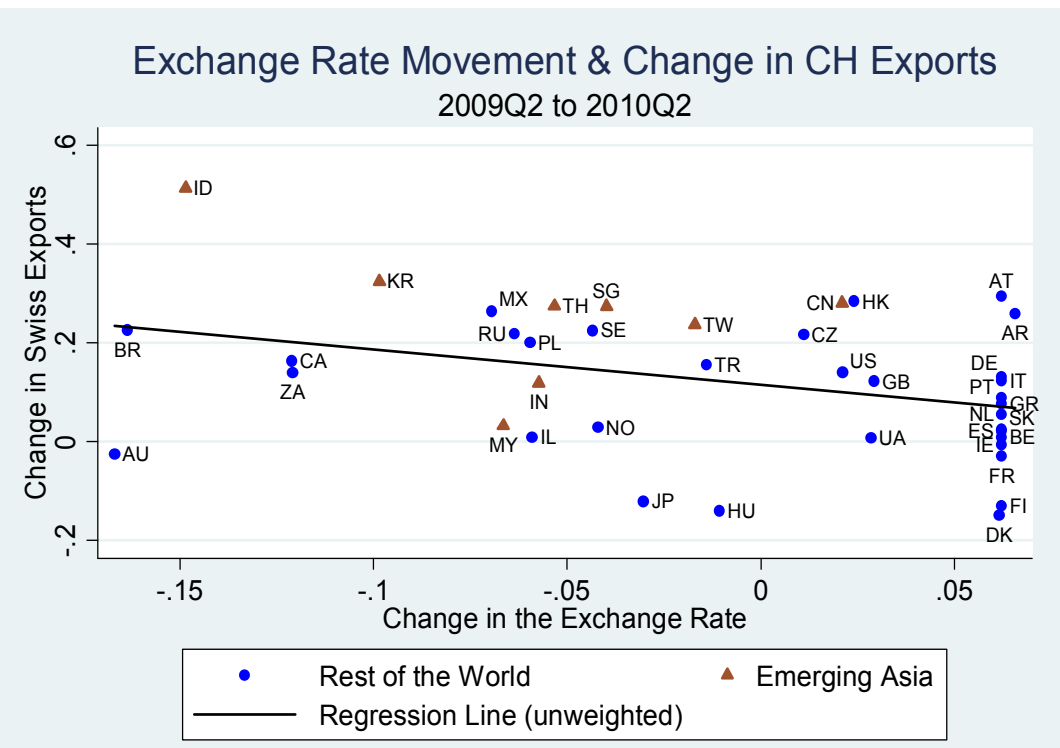

Figure 2

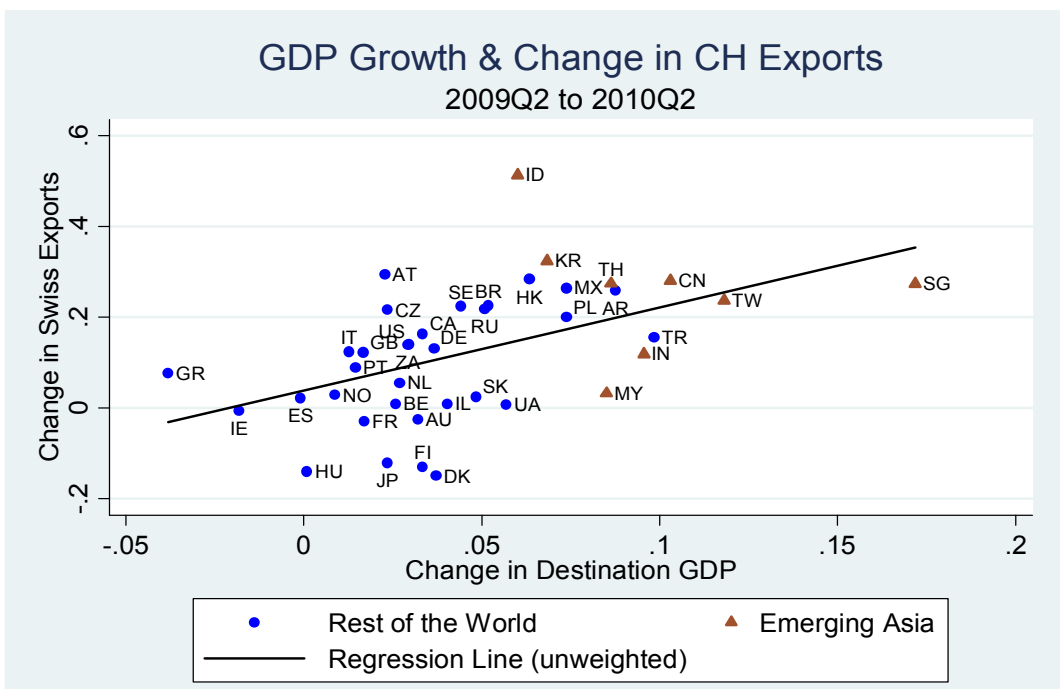

Figure 3

slope of the line in Figure 2 suggest that for each percent more GDP growth of a trading partner, Swiss exports to this partner increase by $1.3 \%$.

Figure 3 also highlights the eight export destinations in Emerging Asia that are included in our sample (triangular red; China, India, Indonesia, Rep. of Korea, Singapore, Malaysia, Taiwan, and Thailand). In these emerging economies, GDP growth has been higher than in the rest of the sample. Consequently, export growth to these emerging economies has also been higher than in the rest of the sample. It is noteworthy, however, that Emerging Asia (apart from Indonesia) is not an outlier: the relationship between GDP growth and export growth also holds for this subsample of countries. 


\subsection{A Gravity Approach}

To go beyond graphical inspection, we next statistically quantify the impact of changes in foreign GDP and exchange rates on Swiss exports. We denote the percentage growth of exports from Switzerland to a trade partner by $\Delta$ Exports $_{C H, \text { TradePartner, }}$, the GDP growth (also in percent) of the trade partner economy by $\Delta G D P_{\text {TradePartner }}$ and the percentage change in the bilateral exchange rate by $\triangle E X R_{C H, \text { TradePartner }}$. Our baseline specification is a standard gravity equation in terms of changes, i.e.

$$
\Delta \text { Exports }_{C H, \text { TradePartner }, s}=\alpha+\beta^{g d p} \Delta G D P_{\text {TradePartner }}+\beta^{\text {exr }} \Delta E X R_{C H, \text { TradePartner }}+\varepsilon_{\text {TradePartner }, s}
$$

In equation (1), the subscript $s$ denotes a sector (time subscripts are omitted for simplicity). We limit the panel to the 27 most important export markets and the 25 largest good categories (see Appendix for a list of these good categories). This subsample covers $40.5 \%$ of total Swiss exports.

We use bilateral trade data on the good level to formally investigate the sensitivity of Swiss exports vis-à-vis bilateral exchange rates and growth of foreign GDP. Our trade data is from the Swiss customs authority (Oberzolldirektion). This data covers the time window of 200501 to 201003 . We obtain data on bilateral exchange rates, as well as GDP data from Datastream. ${ }^{2}$

Table 1 reports the results of the panel regressions. It shows that, in general, an appreciation of the CHF is accompanied by a drop in Swiss exports to the respective economy. The coefficient on the change of the exchange rate in Column $\mathrm{I}$ is estimated at -0.420 , implying that if the CHF appreciates by $10 \%$ against a trade partner's currency, Swiss exports to this trade partner decrease by $4.2 \%$.

Similarly, higher growth rates in a given economy are associated with Swiss exports to the respective economy. The relation between trade partner GDP growth and Swiss exports is significantly positive and the coefficient is estimated at 0.918 , implying that, in the short run, Swiss exports to a given country increase by $9.18 \%$ if this specific country grows by $10 \% .^{3}$

In Columns II and III of Table 1, we add lags of GDP growth and of exchange rate changes to the specification to capture more than just the immediate responses of trade flows to

\footnotetext{
${ }^{2}$ Our sample includes the time quarters from 2005:01 to 2010:Q2. We balance the sample by excluding good-country pairs with zero trade for some of the periods.

${ }^{3}$ The cumulated negative effect of the bilateral exchange rate on Swiss export growth is rather low in magnitude compared to estimated of other studies. In a companion note (see Auer and Saure (2010)), we document that the globally unique composition of the Swiss export basket drives this fact: the Swiss export basket is heavily concentrated in price-insensitive goods, which makes aggregate Swiss exports less responsive to exchange rate changes than exports of other $\mathrm{OECD}$ nations.
} 
the economic environment. We also allow for exports to be autocorrelated. The estimations show the full effect of exchange rate movements and economic growth requires some quarters to materialize. Thus, after three quarters, a one percent appreciation of the CHF has a cumulated direct negative effect of $0.704 \%$ on trade (since -.445-.117-.142=-0.704). ${ }^{4}$ It must be noticed, however, that this direct effect is dampened by the negative autoregressive structure of exports.

Table 1: Explaining Swiss Export Performance

(Random Effect Panel Regression; 200501-201003)

\begin{tabular}{|c|c|c|c|}
\hline & $\mathbf{I}$ & II & III \\
\hline & \multicolumn{3}{|c|}{$\begin{array}{c}\text { Dependent Var: in the Q/Q Percentage Change in a sector's Exports } \\
\text { Switzerland's Top } 30 \text { Export Products }\end{array}$} \\
\hline \multirow[t]{2}{*}{$\begin{array}{c}\% \text { Ch. Bilateral } \\
\text { Exchange Rate }\end{array}$} & $-0.420 * *$ & $-0.403 * * *$ & $-0.445 * * *$ \\
\hline & {$[0.167]$} & {$[0.155]$} & {$[0.151]$} \\
\hline \multirow[t]{2}{*}{ Lag 1} & & -0.136 & -0.117 \\
\hline & & {$[0.153]$} & {$[0.155]$} \\
\hline \multirow[t]{2}{*}{ Lag 2} & & & -0.142 \\
\hline & & & {$[0.159]$} \\
\hline \multirow[t]{2}{*}{ \% Ch. Import GDP } & $0.918 * * *$ & $0.807 * * *$ & $0.908 * * *$ \\
\hline & {$[0.146]$} & {$[0.136]$} & {$[0.135]$} \\
\hline \multirow[t]{2}{*}{ Lag 1} & & $0.395 * * *$ & $0.607 * * *$ \\
\hline & & {$[0.128]$} & {$[0.131]$} \\
\hline \multirow[t]{2}{*}{ Lag 2} & & & $0.613 * * *$ \\
\hline & & & {$[0.126]$} \\
\hline \multirow[t]{2}{*}{$\begin{array}{r}\text { Lag } 1 \text { of } \% \text { Ch. } \\
\text { Exports }\end{array}$} & & $-0.406 * * *$ & $-0.521 * * *$ \\
\hline & & {$[0.0354]$} & {$[0.0368]$} \\
\hline \multirow[t]{2}{*}{ Lag 2} & & & $-0.259 * * *$ \\
\hline & & & {$[0.0315]$} \\
\hline \multirow[t]{2}{*}{ Constant } & $0.0141^{*}$ & $0.0186^{* * *}$ & $0.0164 * *$ \\
\hline & {$[0.00724]$} & {$[0.00712]$} & {$[0.00762]$} \\
\hline Number of Sectors & 27 & 27 & 27 \\
\hline No. of Trade Partners & 25 & 25 & 25 \\
\hline Observations & 10048 & 9567 & 9086 \\
\hline R-squared & 0.007 & 0.175 & 0.242 \\
\hline \multicolumn{4}{|c|}{$*$ significant at $10 \% ; * *$ significant at $5 \% ; * * *$ significant at $1 \%$} \\
\hline
\end{tabular}




\section{Swiss Exports Performance Disaggregated at the Industry and the Geography Dimension}

Table 1 allows a first assessment of the impact of the bilateral exchange rates and GDP in export markets on Swiss exports. It takes into account that demand growth in each trade partner and the bilateral exchange rate vis-à-vis each trade partner matter for Swiss export growth. However, the specifications of Table 1 require that all good categories react in the same way to shocks to exchange rates and GDP. We relax this assumption next and allow industries to differ in the respect to which they react to these shocks.

The impact of exchange rate changes and GDP growth is different for distinct good categories. Figure 4 nicely illustrates this fact by depicting the recent (aggregate) export performance for "Pharmaceuticals" and "Mechanical Watches". 5

While mechanical watches saw a heavy collapse during the crisis, the export volume of pharmaceuticals appears

\section{Resilient vs. Non-Resilient Goods: Two Examples}

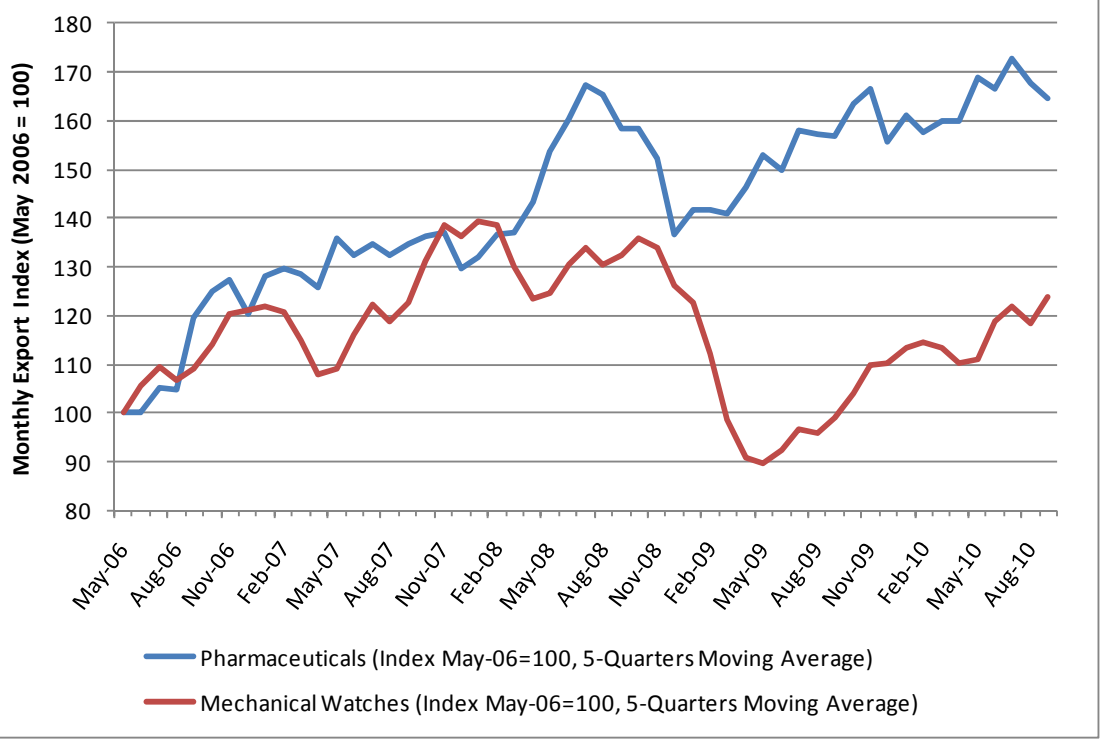

Figure 4 to be largely unaffected by the collapse of world trade that in late 2008.

Demand for different types of goods is affected differently by macroeconomic shocks. We next adjust our econometric approach to adjust for this heterogeneity. ${ }^{6}$ That is, we turn to a more refined exercise and re-estimate the empirical model (1) allowing the coefficients $\beta$ to vary across good classifications.

\footnotetext{
${ }^{5}$ The Precise definition of mechanical watches is "Uhrmacherware, mit mech. Aufzug" and the one of pharmaceutics is "Arzneiwaren, andere".

${ }^{6}$ Further, estimations of the coefficients on the aggregate level induces potentially serious aggregation bias as pointed out in Imbs and Méjean (2008).
} 
Given the finding from Table 1 that also lagged changes of the exchange rate and GDP growth matter, we estimate

$$
\begin{aligned}
\Delta \text { Exports }_{C H, \text { TradePartner }, s}=\alpha_{s}+ & \sum_{k=0}^{3} L^{k} \beta_{s, k}^{(g d p)} \Delta G D P_{\text {TradePartner }, s}+\sum_{k=0}^{3} L^{k} \beta_{s, k}^{(\text {exr })} \Delta E X R_{C H, \text { TradePartner }, s} \\
& +\sum_{k=1}^{3} L^{k} \beta_{s, k}^{\text {tra }} \Delta \text { Exports }_{C H, \text { TradePartner }, s}+\varepsilon_{\text {TradePartner }, s}
\end{aligned}
$$

where $L$ is the lag operator. We then aggregate the identified good-specific effects by weighting according to the volume of bilateral exports. In this way, we do not only account for the differences across goods regarding demand elasticity to the exchange rate and GDP, but also capture the compositional effect arising from the export basket to vary across Switzerland's trade partners.

We run this exercise using our sample of 27 countries and 25 goods. Figure 5 illustrates a decomposition of demand and price effects. It shows the actual growth of quarterly Swiss exports (bold blue line) and three types of contributions to this increase: the part that is explained by the growth of GDP in Switzerland's export markets (green line), the part that is explained by the evolution of the CHF against the trade partner currencies (red line), and last, the part that is explained by the presence of autoregressive terms including a residuum (dashed line).

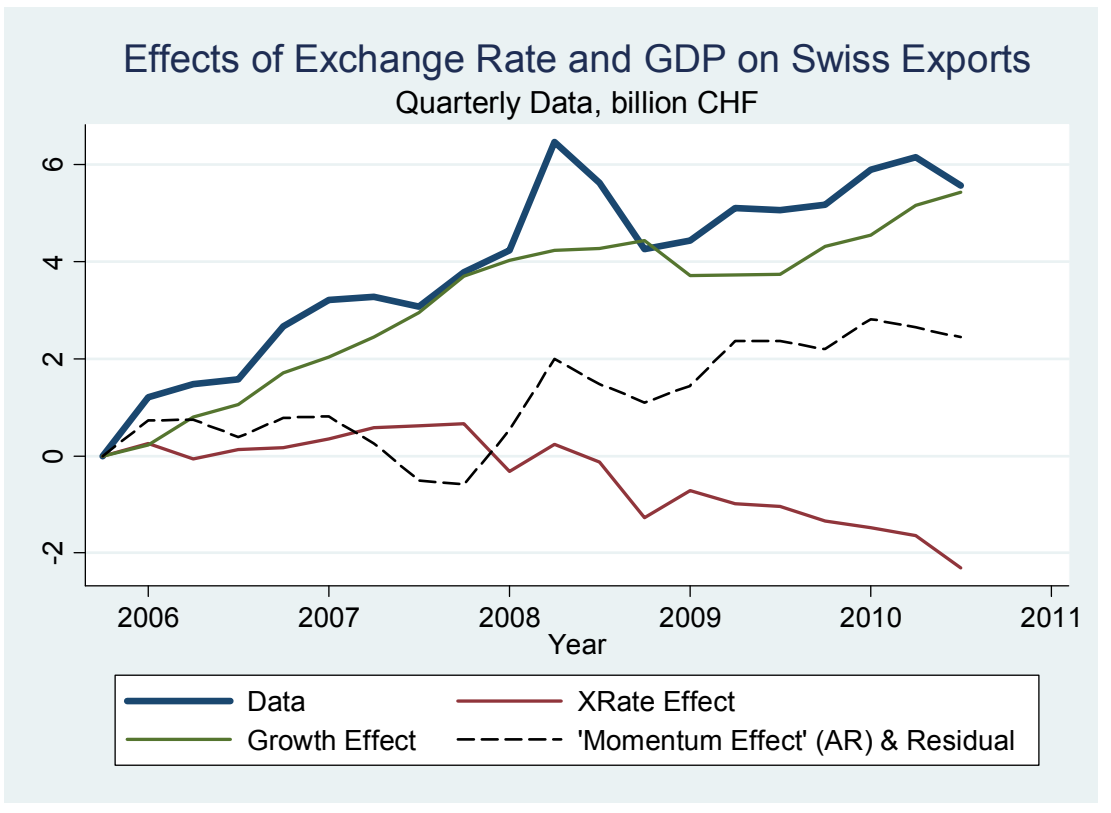

Figure 5

Figure 5 documents that the CHF strength has had a pronounced negative effect on Swiss export performance during the recent years. Figure 5 also documents that the only reason why the CHF strength never led to a decrease in the volume of Swiss exports was the coincidence of global recovery and CHF strength: the pronounced CHF appreciation happened exactly when global demand recovered strongly. Failure to account for this 
coincidence might lead to the wrong assumption that the exchange rate matters very little for Swiss export performance.

Over the entire sample length global demand growth dominated the CHF strength: within the period of 200504 to 2010Q3, demand growth from Switzerland's trade partners has contributed to an increase of quarterly exports in our sample by CHF 5.4 billion.

\section{The Effect of the CHF Strength on Swiss Exports.}

We next use these findings to gauge the total effect of the recent CHF strength on the volume of Swiss exports. To come up with the relevant numbers, we estimate how much higher the total volume of Swiss exports would have been if all bilateral exchange rates had remained at their October 2005 level. For example, on that date, the CHF/euro exchange rate was 1.544 . We predict our earlier models using this scenario and we also take into account that our sample in the previous analysis only covers $40.5 \%$ of Swiss trade.

The appreciation of the CHF has considerably dampened Swiss export performance. Figure 6 documents the difference in quarterly trade flows compared to the scenario where the CHF stayed flat against other currencies during the 5 years leading up to October 2010. A positive value means that Swiss exports were higher than they would have been had the CHF remained at its October 2010 level. Correspondingly, a negative value documents a loss due to the recent CHF strength.

Since the start of the lost a combined in CHF 35 billion in revenue due to the CHF appreciation. Compared to this scenario, the Swiss export industry actually gained a few billion CHF in revenue due the CHF weakness in 2007.

Starting in 2008, however, the strong CHF appreciation has lead to large losses. These losses amounted to around CHF 2.5 billion per quarter in 2009 and then more than tripled with the more continuing appreciation during 2010. Overall, the cumulative export losses until 01.01.2011 exceed CHF 35 billion.

Also at the current juncture, the CHF strength continues to harm Swiss exporters. Compared to the scenario with October 2010 exchange rates, exports are approximately CHF 7.8 billion per quarter lower. This is equivalent to 17\% of Swiss 042010 exports (that were equal to around CHF 48 billion). 
Figure 6 documents the likely effect of the CHF appreciation during 2011. For these projections, we assume that the CHF stays at the current rate of around 1.30 CHF/EUR. With this rate, the total cumulative loss due to the appreciation is expected to be around CHF 67 billionat the end of 2011.

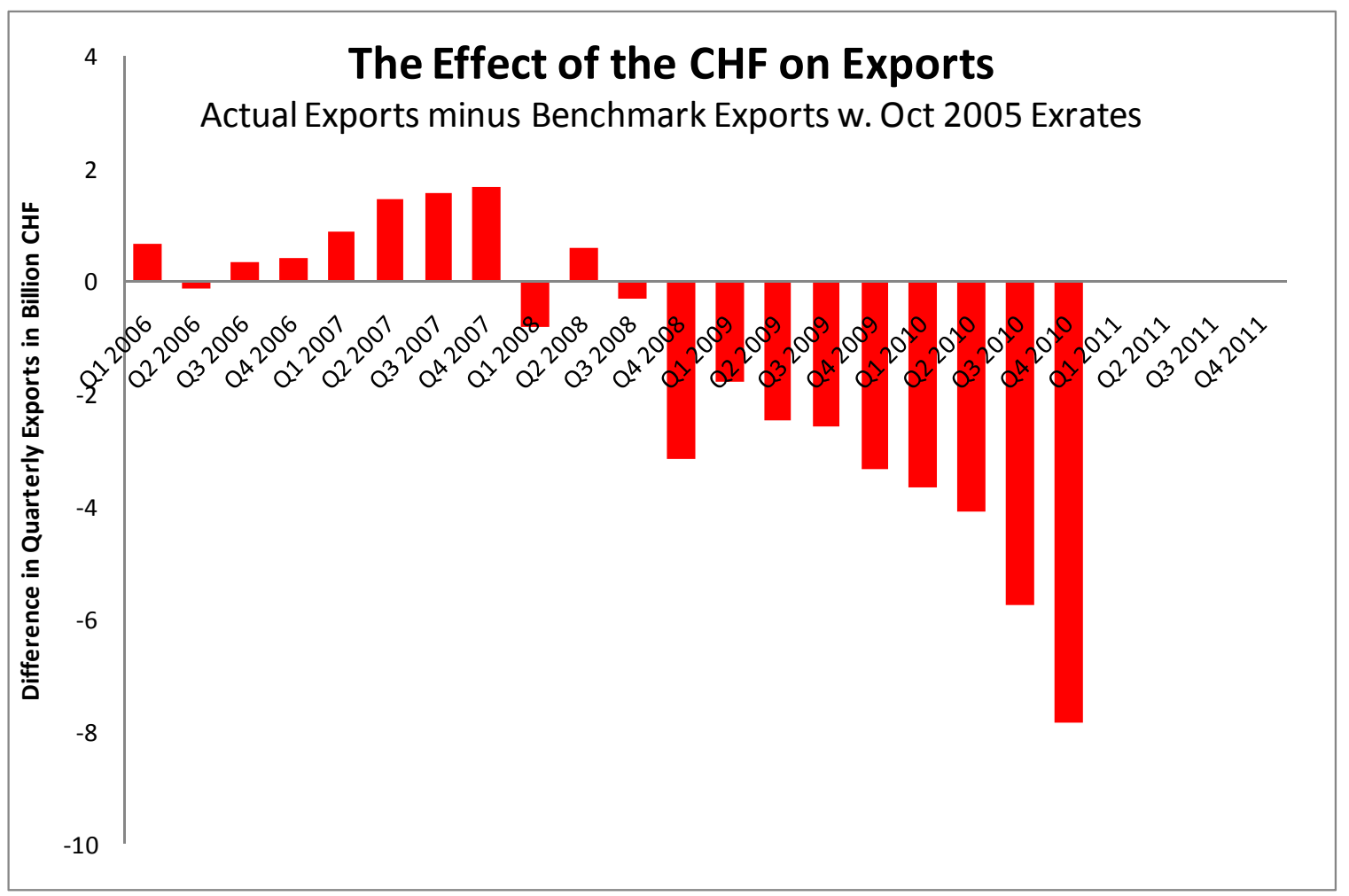

Figure 6 Actual Exports Minus Benchmark Exports with October 2005 Exchange Rates (from Q1 2011 on forecast)

\section{Export Outlook Based on SNB's Macroeconomic Forecasts}

The previous analysis has identified the relation between changes in the exchange rate, changes in importer GDP, and Swiss export growth. We next utilize the estimation results obtained using this historical data and current GDP and exchange rate forecasts to predict the likely evolution of Swiss exports as well as its geographic composition.

For our predictions, we employ the current SNB forecasts of economic growth and exchange rates for the main economic regions of the world. The regions covered by the SNB forecast data are Germany, France, the remaining euro area (i.e. Belgium, Finland, Greece, Ireland, Italy, Luxembourg, Malta, The Netherlands, Austria, Portugal, Slovak Rep., Slovenia, Spain, Cyprus), UK, US, Japan, and Emerging Asia (defined here as Mainland China, Hong Kong, Singapore and Taiwan).

The GDP forecasts are available for the period 201101 to 201304. They are in real 2000 local currencies. We therefore deflate out trade data with the Swiss CPI index. The data include historical data that cover the period of our estimation (200501-201003). We use 
both, historical and forecast data, from the same source. Exchange rate forecasts are available for 201101 to 201204, which we extend up to 201304 by assuming constant bilateral exchange rates thereafter. ${ }^{7}$

Using data from these sources, we estimate equation (2), where we aggregate trade data on the 2-digit good level to balance the sample. Figures $A 1$ and $A 2$ in the Appendix report the estimated coefficients $\beta$ from specification (2), showing substantial variation between the good classifications. We next use these estimates to compute, for each region separately, the weighted average of the respective coefficient. For example, the aggregated coefficient for Germany (DE) of the $k^{\text {th }}$ lag of GDP is

$$
\hat{\beta}_{k, D E}^{g d p}=\sum_{s=1}^{95} w_{D E, s} \hat{\beta}_{k, D E, s}^{g d p}
$$

where $w_{D E, s}$ is the share of sector $s$ in the export basket to region $D E$. Hats indicated estimated coefficients. We use these coefficients to predict trade volumes with the different economic regions, based on the SNB growth and exchange rate forecasts.

Figure 7 plots these forecasts of Swiss exports (dashed lines) together with historical data (solid lines), disaggregated by the seven regions. Total exports are predicted to grow by a total of $16.2 \%$ over the next three years (between 201004 and 201304).

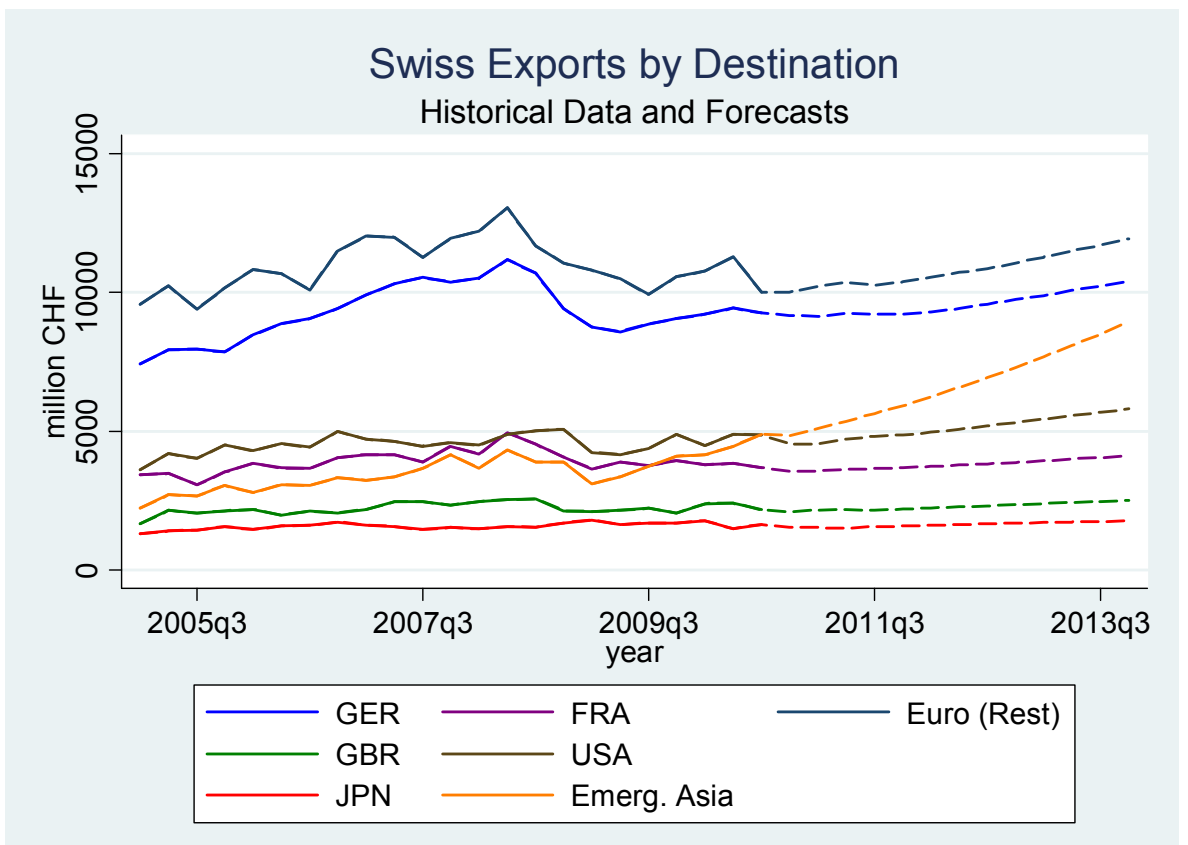

Figure 7

\footnotetext{
${ }^{7}$ Economic Analysis does not provide a forward estimate for the exchange rate of Emerging Asia. We assume that the exchange rate will appreciate by $3 \%$ against the USD in the course of the next 12 months, as is currently predicted by 12 -month non-deliverable forwards for the Chinese Renminbi. Thereafter, we assume that the exchange rate will stay flat compared with the USD.
} 
A striking element is the impressive growth of exports to Emerging Asia, which is predicted to contribute $44.6 \%$ of the total rise in export volume over the next three years. This result is, of course, the consequence of high growth rate that the Economic Analysis unit of the Swiss National Bank predicts for Emerging Asia (an average of 7.6\% yearly growth compared with corresponding numbers of 3.4\% for the US, $2.3 \%$ for Germany, $2.4 \%$ for France and $2.6 \%$ for the rest of the Euro Area). Of course, the projections of trade with Emerging Asia may be dampened if the local exchange rate basket appreciated by more that the predicted $2.7 \%$ vis-à-vis the CHF.

Interestingly, the euro area excluding Germany and France is predicted to contribute a sound $17.1 \%$ to the total rise, despite the continued strength of the CHF vis-à-vis the euro. Since growth predictions are not exceptional for that region, this feature reflects to a large extent a compositional effect of the export basket. Trade with the other regions picks up only moderately. The exact contributions of the seven different regions are listed in Table 2.

Table 2: Swiss Exports by Region

(million CHF, 2010 actual, 2011-13 predicted)

\begin{tabular}{|c|c|c|c|c|c|c|}
\hline country & 2010 & 2011 & 2012 & 2013 & $\begin{array}{c}\text { Increase } \\
2010-13(\%) \\
\end{array}$ & $\begin{array}{c}\text { Contribution } \\
\text { to Increase }\end{array}$ \\
\hline GER & $33^{\prime} 451.53$ & $32^{\prime} 926.91$ & $33^{\prime} 435.21$ & $34 ' 816.18$ & $4.1 \%$ & $6.4 \%$ \\
\hline FRA & $13 ' 510.66$ & $13^{\prime} 653.79$ & $14^{\prime} 226.01$ & $14^{\prime} 957.32$ & $10.7 \%$ & $6.8 \%$ \\
\hline Euro (Rest) & $37^{\prime} 900.57$ & $37^{\prime} 711.68$ & $39^{\prime} 257.13$ & $41 ' 564.35$ & $9.7 \%$ & $17.1 \%$ \\
\hline GBR & 8'197.99 & $8^{\prime} 316.76$ & $8^{\prime} 765.17$ & 9'367.83 & $14.3 \%$ & $5.5 \%$ \\
\hline USA & $16^{\prime} 967.13$ & $17^{\prime} 738.23$ & $18^{\prime} 894.48$ & $20^{\prime} 298.54$ & $19.6 \%$ & $15.6 \%$ \\
\hline JPN & $5^{\prime} 865.56$ & $6^{\prime} 072.49$ & $6^{\prime} 409.56$ & $6^{\prime} 747.72$ & $15.0 \%$ & $4.1 \%$ \\
\hline Emerg. Asia & $16 ' 539.01$ & $19^{\prime} 222.25$ & $22^{\prime} 409.71$ & $26^{\prime} 096.77$ & $57.8 \%$ & $44.6 \%$ \\
\hline Total & $132^{\prime} 432.45$ & $135^{\prime} 642.11$ & $143^{\prime} 397.27$ & $153^{\prime} 848.71$ & $16.2 \%$ & $100.0 \%$ \\
\hline
\end{tabular}

Turning to predictions at the good level, Table 3 lists a selection of the most important export sectors, listing both the predicted growth of exports to the world and the growth of exports to Emerging Asia. A description of the tariff classes is included in the Appendix. The table suggests that demand growth will primarily come from East Asia for specialized machinery (Tarifnr. 3302) and perfumery products (Tarifnr. 3302), while demand will generally be strong for pharmaceutical products (Tarifnr. 3002) and watches (Tarifnr. 9101). 
Table 3: Swiss Exports by Good Classification

\begin{tabular}{|c|c|c|c|c|c|c|}
\hline \multirow[b]{3}{*}{ Tarifnr. } & \multicolumn{6}{|c|}{ (million CHF, predicted) } \\
\hline & \multicolumn{3}{|c|}{ World } & \multicolumn{3}{|c|}{ Emerging Asia } \\
\hline & 2010 & 2013 & Increase (\%) & 2010 & 2013 & Increase (\%) \\
\hline 2933 & 4414 & 5558 & $25.9 \%$ & 534 & 918 & $71.9 \%$ \\
\hline 2937 & 1991 & 2171 & $9.0 \%$ & 1 & 1 & $-40.6 \%$ \\
\hline 3002 & 11483 & 22510 & $96.0 \%$ & 483 & 1210 & $150.5 \%$ \\
\hline 3004 & 17480 & 20880 & $19.5 \%$ & 1080 & 1380 & $27.8 \%$ \\
\hline 3302 & 1049 & 1084 & $3.4 \%$ & 39 & 54 & $39.6 \%$ \\
\hline 7113 & 3266 & 4160 & $27.4 \%$ & 826 & 1410 & $70.7 \%$ \\
\hline 8481 & 1112 & 1391 & $25.1 \%$ & 173 & 321 & $85.5 \%$ \\
\hline 9018 & 1743 & 1930 & $10.7 \%$ & 93 & 130 & $39.5 \%$ \\
\hline 9021 & 4692 & 5332 & $13.6 \%$ & 172 & 242 & $40.7 \%$ \\
\hline 9101 & 3690 & 5990 & $62.3 \%$ & 1890 & 3870 & $104.8 \%$ \\
\hline
\end{tabular}

\section{Conclusion}

The current strength of the CHF did have a substantial negative effect on the Swiss export performance and has already cost the Swiss exports sector CHF 35 billion in revenues. This effect, however, was masked by the fact that CHF strength and global demand recovery coincided.

We show that the key reason for the strong export performance despite the CHF strength was the rebound in global demand in the aftermath of the financial crisis. However, the timing of global demand growth has completely masked the effect of the CHF strength: during the last quarters, periods of pronounced CHF appreciation always coincided with strong recovery of global demand. Failure to account for this coincidence could lead to the wrong assumption that the exchange rate matters little for Swiss export performance.

Last, we gauge the likely evolution of Swiss exports and their regional composition in the years to come. We predict that over the next three years, Swiss exports will rise a combined 16\%, with little less than half of this increase going to Emerging Asia and $30 \%$ to the euro zone. 


\section{Appendix}

\section{Countries in Regression to Table 1}

Austria, Australia, Belgium, Brazil, Canada, China, Czech Republic, Germany, Denmark, Spain, France, UK, Greece, Hong Kong, India, Italy, Japan, South Korea, Mexico, Netherlands, Portugal, Russia, Sweden, Singapore, Thailand, Turkey, US.

\section{Tariff-Number}

22029090，2716.0000，2924.2920，2933.9910，2937.1900，2941.9000， 3002.1000， 30042000，3004.3900，3004.9000，3302.9000，8411.9900，8479.8942，88023000， 8802.4000, 9018.9000, 9021.1000, 9021.3100, 9021.5000, 9021.9000, 91011100, $9101.2100,9101.2900,9102.1100,9102.2100$

\section{Tariff-Numbers -Selected Classifications (4-digit level)}

\section{Tarifur. Beschreibung}

2933 Heterocyclische Verbindungen mit ausschliesslich Stickstoff als Heteroatom(e)

2937 Hormone, Prostaglandine, Thromboxane und Leukotriene, natürliche oder synthetisch hergestellte; ihre Derivate und strukturellen Analoge, einschliesslich Polypeptide mit modifizierter Kette, hauptsächlich als Hormone verwendet

3002 Menschliches Blut; tierisches Blut, zu therapeutischen, prophylaktischen oder diagnostischen Zwecken zubereitet; Antisera, andere Blutfraktionen, modifizierte immunologische Erzeugnisse, auch auf biotechnologischem Wege gewonnen; Vaccine, Toxine, Kulturen von Mikroorganismen (ausgenommen Hefen) und ähnliche Erzeugnisse

3004 Arzneiwaren (ausgenommen Erzeugnisse der Nrn. 3002, 3005 oder 3006), bestehend aus gemischten oder ungemischten zu therapeutischen oder prophylaktischen Zwecken zubereiteten Erzeugnissen, dosiert (einschliesslich derer, welche zur perkutanen Verabreichung bestimmt sind) oder in Aufmachungen für den Einzelverkauf

3302 Mischungen von Riechstoffen und Mischungen (einschliesslich alkoholischer Lösungen) auf der Grundlage eines oder mehrerer dieser Stoffe, der als Industrierohstoffe verwendeten Art; andere Zubereitungen auf der Grundlage von Riechstoffen, der zum Herstellen von Getränken verwendeten Art

7113 Bijouterie und Juwelierwaren und Teile davon, aus Edelmetallen oder Edelmetallplattierungen

8481 Armaturen und ähnliche Apparate für Rohr- oder Schlauchleitungen, Dampfkessel, Sammelbehälter, Wannen oder ähnliche Behälter, einschliesslich Druckminderventile und thermostatisch gesteuerte Ventile

9018 Instrumente, Apparate und Geräte für medizinische, chirurgische, zahnärztliche oder tierärztliche Zwecke, einschliesslich Apparate und Geräte für die Szintigrafie und andere elektromedizinische Apparate und Geräte sowie Apparate und Geräte zum Prüfen des Sehvermögens

9021 Apparate und Vorrichtungen zu orthopädischen Zwecken, einschliesslich medizinischchirurgische Gürtel und Bandagen sowie Krücken; Schienen, Rinnen und andere Apparate und Vorrichtungen zum Behandeln von Knochenbrüchen; Prothesen; Schwerhörigenapparate und andere Vorrichtungen zum Beheben von Funktionsschäden oder Gebrechen, zum Tragen in der Hand, auf dem Körper oder zum Einpflanzen in den Organismus

9101 Armbanduhren, Taschenuhren und ähnliche Uhren (einschliesslich Stoppuhren vom gleichen Typ), mit Gehäuse aus Edelmetallen oder Edelmetallplattierungen 


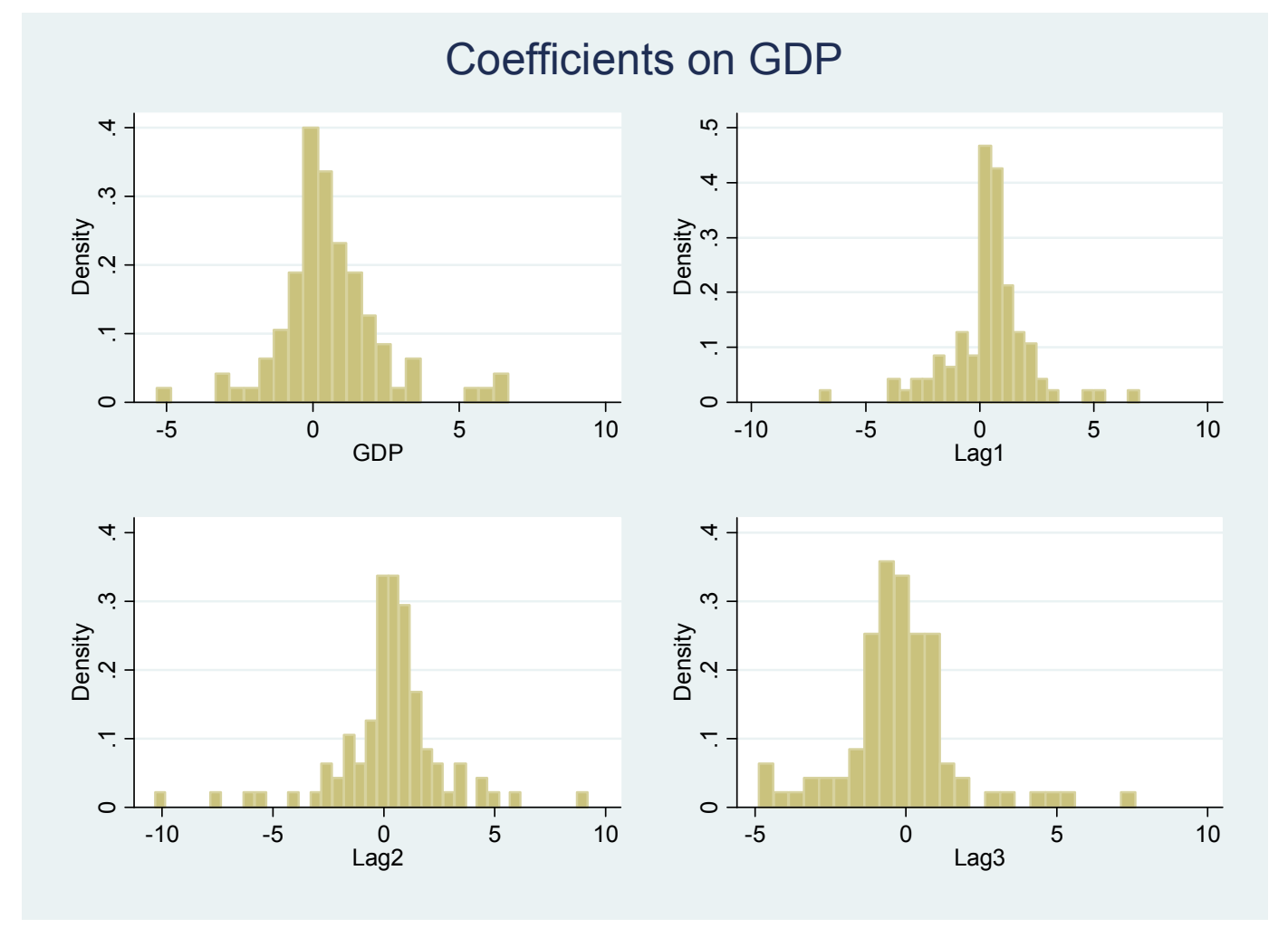

Figure A1

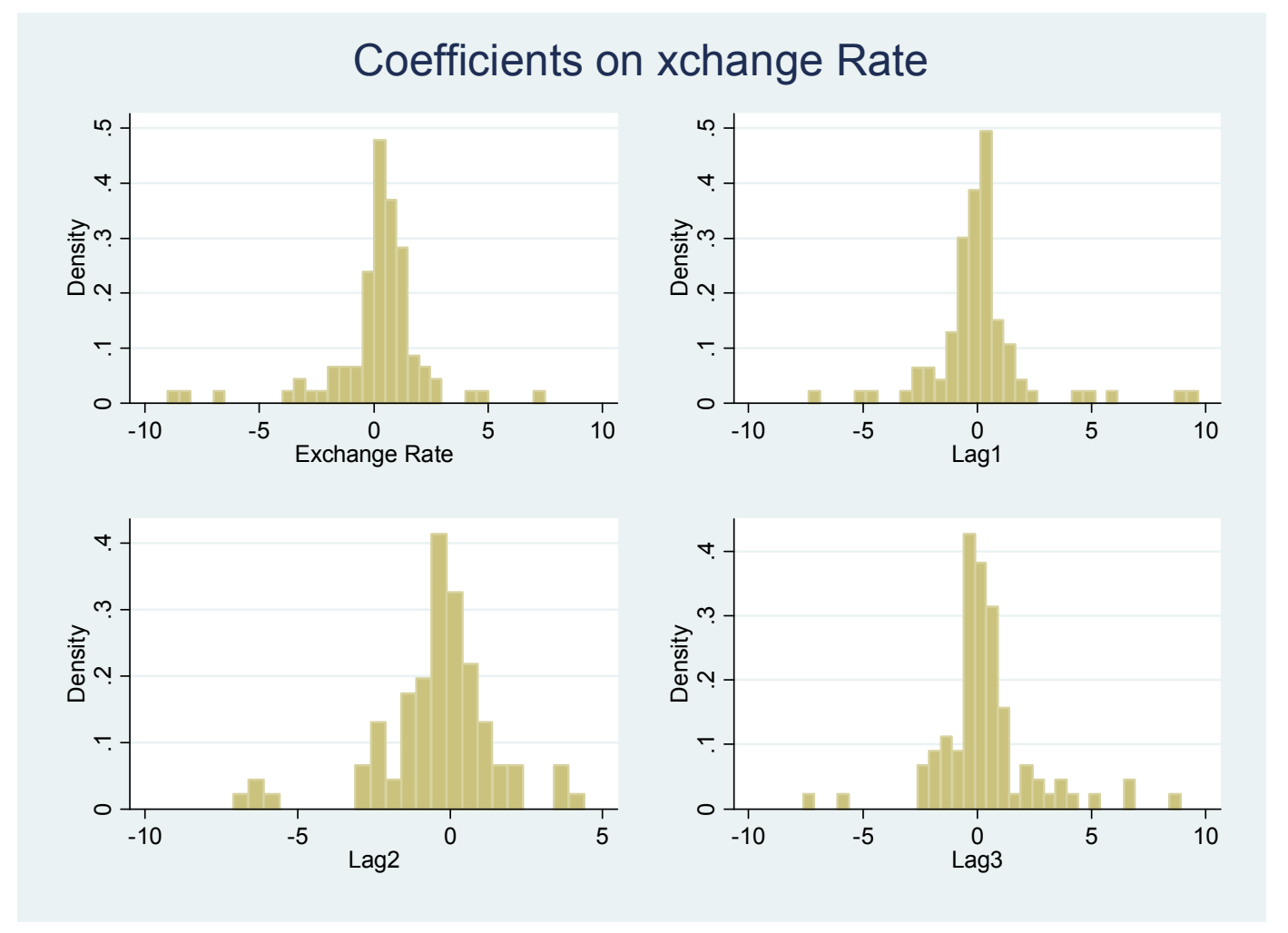

Figure A2 


\section{References}

Raphael Auer and Philip Sauré (2011). “Industry Composition and the Effects of Exchange Rates on Exports - Why Switzerland is Special?", Globalization and Monetary Policy Institute Working Paper 77, Federal Reserve Bank of Dallas. April 2011

Anderson, James E. and Eric van Wincoop (2003). "Gravity with Gravitas: A Solution to the Border Puzzle," American Economic Review, American Economic Review, Vol. 93(1), pages 170-192, March.

Broda, Christian, and David Weinstein (2006). "Globalization and the Gains from Variety." The Quarterly Journal of Economics, 121 (2): 541--585.

Philipp Hildebrand, Monetary policy challenges: Swiss exports in a globalised world, Talk Held at the Swiss Mission the European Union, Brussels on 23.11.2010

Imbs, Jean M. and Isabelle Méjean 2009: "Elasticity Optimism" International Monetary Fund WP 09/279

Caroline Schmidt (2009) "Is Switzerland different? The role of trade in the current crisis" Research Note, Economic Analysis, 05 October 2009

Thierry Tressel (forthcoming), Selected Issues Paper for the 2011 Switzerland Article IV Consultation: Impact of Exchange Rate Movements on Export Performance and Consumer Prices, International Monetary Fund, forthcoming 